\title{
Determining The Factors Affecting Brand Equity in A Development Organization Through Survey
}

\author{
Hassan Javanshir ${ }^{1}$, Reza Allahyari Soeini ${ }^{2}$ \\ ${ }^{1}$ Department of Industrial Engineering, South Tehran Branch, Islamic Azad University, Tehran, Iran \\ Email: h.javanshir.azad@gmail.com \\ ${ }^{2}$ Department of Industrial Engineering, South Tehran Branch, Islamic Azad University, Tehran, Iran \\ Email: reza.allahyarisoeini@gmail.com
}

\begin{tabular}{|c|c|}
\hline ARTICLE INFO & ABSTRACT \\
\hline $\begin{array}{l}\text { Keywords: } \\
\text { Brand Equity } \\
\text { Brand Valuation } \\
\text { Brand Evaluation } \\
\text { Brand Value } \\
\text { Intangible Asset } \\
\text { Evaluation } \\
\text { Intangible Asset } \\
\text { Valuation } \\
\text { Intangible Asset } \\
\text { Value }\end{array}$ & $\begin{array}{l}\text { Generally, brand equity valuation methods are divided into two } \\
\text { categories: qualitative methods and quantitative methods. In the } \\
\text { qualitative approach, the main issue is the customer's view of the } \\
\text { brand. Qualitative issues like familiarity, trust, loyalty and etc. and } \\
\text { financial issues of the company are like price premiums, legal issues, } \\
\text { value added to products and etc. This project seeks to investigate some } \\
\text { of the brand equity valuation models and determining factors affecting } \\
\text { it in scientific articles. In order to do this, firstly we searched some } \\
\text { related keywords in two scientific databases (Emerald Insight and } \\
\text { Science Direct). Then we examined obtained articles and extract the } \\
\text { brand valuation models and factors out of them. In the end, after } \\
\text { extracting a variety of models and indexes, the experts of an } \\
\text { development organization were asked the most important factor } \\
\text { affecting brand equity and the result was presented. }\end{array}$ \\
\hline
\end{tabular}

\section{Introduction}

In general, organizational assets can be divided into two categories: tangible assets and intangible assets. One of the most important intangible assets of an organization is its brand (Aaker, 1991). There are different viewpoints on brand. Many strategic business decisions, in addition to the evident values, are dependent on intangible values like brand (Aaker, 1991; Harjoto, 2017). two reasons for measuring brand equity, is pointing out the rational pricing for the products and stocks of the company and decision making in the field of marketing planning. Also measuring brand equity can play an important role in order to purchasing or selling an organization or in order to merging some organizations with each other (Aaker, 1991; Mishra 2017).

The research method used in this study was meta-analysis. In this study, 216 articles were extracted from the Emerald Insight and Science Direct scientific databases. In order to extract these articles, Brand Equity, Brand Valuation, Brand Evaluation, Brand Value, Intangible Asset Evaluation, Intangible Asset Valuation and Intangible Asset Value keywords were used. The period in which articles were searched was between 1985 and 2017. All articles were in English. In the first stage, the articles were reviewed regarding the relevance of the title, abstract and conclusion to the subject of this research. Then, Critical Appraisal Skills Program (CASP) was used, which is a qualitative evaluation method. In the CASP method, ten qualitative terms are designed to evaluate each article

* Corresponding author at: Department of Industrial Engineering, South Tehran Branch, Islamic Azad University, Tehran, Iran.

E-mail address: reza.allahyarisoeini@gmail.com 
in a qualitative way. Each article is faced with these terms, with a score of 1 to 5 . Articles with a total score of 25 and above would be qualitatively verified and the remaining articles were omitted. The conditions for the CASP method in this research are as follows: 1- The relevance of the objectives of the article examined to the objectives of the following research; 2- The research logic of the article under consideration; 3- The proposed scheme in the article; 4- The under review article method of sampling; 5- The manner and quality of the data collected in the under review article; 6- Reflection level (the possibility of expanding the results and achievements) of the under review article; 7- The rate and manner of observance of common ethical points in the writing of research texts; 8- The accuracy of data analysis in the article; 9- The clarity of expression in the presentation of the findings of the article; 10 - The overall value of the article under review. The researcher evaluated the article qualitatively by giving a score for each question to each article. The result of the review of these articles was 20 suitable articles for the subject of following research.

\section{Literature Review}

Based on selected articles, the key points of their findings are as follows:

Murphy had claimed that some brand valuation methods are flawed. These methods include: Evaluation methods based on total cost: advertising and research, and brand development costs; pricing based on premium prices; evaluating market value; evaluating based on consumer. He'd believed that the following should be considered in the brand assessment: marketing, financial and legal matters; basic accounting concepts and corporate rules. One belief in his view was that international brands are inherently more valuable than national or regional brands (J. Murphy, 1989). Blackett had considered brand assessment to be a brand strength assessment. His theory was as follows: An evaluation of a brand has three stages: 1. Assessing the current strength of the brand (and thus the ability to generate future cash flows); 2 . Determining the various earnings of company; 3 . Use of earnings in brand profitability (a very important factor in determining value). He'd believed that brand strength is a combination of seven factors: leadership: a brand that leads a part of the market is stronger than the brand that follows; Stability: Stamped brands with stronger loyal customers; market of brand; internationality potential of brand; brand progress: ability to stay in the market and its position in line with its customers; support: the quality and extent of sponsor protection from the brand; protection: importance of protecting the brand equity (Blackett, 1991). Generally, brand valuation methods are divided into two main groups. Quantitative methods and qualitative methods. The pioneers in quality theorizing of brand value were Professor Aaker and Professor Keller. In many reviewed articles, the opinions of these two scientists were mentioned. Aaker considers brand equity to be based on the four factors. These four factors are: Brand Loyalty: Creates a strong commitment to re-purchasing despite marketing actions that change behavior; perceived quality: judging and preferring a product to other products; brand awareness: knowing and remembering the existence of the brand in market, associations: the association of anything related to the brand the minds of consumers" (Aaker, 1991) ${ }^{1}$. Sharma is another theorist who believed brand equity can be valuate in two ways. One way through the financial indicators and another one through the customer's opinions about that brand. According to Sharma, brand equity was divided into two parts: Brand Strength and Brand value. In fact, like Blackett, she believed the brand's core value was its strength. She had claimed that customer-based brand pricing has five dimensions: perceived quality, perceived value, image, trust, and commitment (Lassar et al., 1995). A model for brand equity pricing was introduced by Motameni and Shahrokhi (1998), called the

\footnotetext{
${ }^{1}$ This reference is a book.
} 
Global Model. Different views on brand equity evaluation views had surveyed in this article. These views were: From a marketing perspective: brand value contributes to the improvement of its marketing; from a financial standpoint: the company's financial revenue differentials relating to the brand; the global perspective: the combination of previous views plus A global look at it, because a brand may have a lot of worth in a market and less worth in another market. In order to determining brand strength, these issues should be considered: brand position, market, competitive conditions and previous brand performance (Motameni, Shahrokhi, 1998). Information theory, based on the theory of Keller and Higinz, considers two factors of content and experience in customer information to be the determining factors of a brand's value. About the first factor, in the mind of the customer, the good quality of a product is attributed to its assignment to a good brand, and in the factor of experience, the amount of recall time of a brand in the customer's mind makes it preferable when choosing a product (Krishnan, 2013). Steenkamp (2014) claimed that four factors should be evaluated in order to measure the value of a company: 1. Brand 2. Resources 3. How to Deliver (products) 4. Work output (Steenkamp, 2014). An important factor in brand valuation is its responsiveness. In a study done by Zhang, two types of brands were compared: active brand and responsive brand. Measured factors were: customer familiarity, trust and loyalty to the brand. The results of this research are as follows: Both brand models have a positive effect on familiarity factor, but the brand is more effective. Responsive brand effect is positive on trust and loyalty factors, but the active brand has a negative effect somewhat. (Zhang, 2014). In Abril's (2016) paper, the impact of retailer marketing elements used to protect their private labels was tested on the value of their brands. These include: the distribution of products, the price, the amount of advertising costs, the in-store marketing activities: such as providing samples for product quality testing and in-store communications (Abril, 2016). In the article Lin (2016), the relationship between firm strength and weakness with the volume of corruption in it and the resulting on brand equity was examined. The research shows that the stronger a company is, the less corruption it has, and as a result, customers are more likely to make the products they need. Therefore, their brand equity will increase. (Lin, 2016) The impact of the tourism industry on the brand equity of a country was studied in a paper (Chow, 2016). According to the results of this study, brand equity of companies that exists in touristic countries increase. In the paper (Godey, 2016), the impact of social media marketing on brand equity had examined. Social media, with a two-way impact on brand values, such as brand image and brand awareness, have a positive and significant effect on consumer behavior towards brands. Another model is Herrero brand pricing, which emphasized on the image of the country and brand in the minds of the customer. (Herrero et al, 2015). Another valuation model is about a brand that imitates an innovative design from another brand. Brand equity factors in this model included brand image, brand priority, brand credibility, brand leadership, and brand equity. Results showed that all indicators in the following brand were lower than the original brand (Vogel, 2017). The next model was the valuation framework for brands of the retail industry. In this model, the seven structured dimensions in a four-step process are presented as follows: 1- Knowledge, 2- Price policy, 3- Customer service, 4- Product quality, 5Physical store, 6- trust to retailer and 7- Loyalty to Retailers (Anselmsson, 2017). Another factor affecting the brand value of a company is the unity between companies and the extent of their unity. In a research, the impact of the multi-brand companies' unity on their brand value has been measured (Mishra, 2017). Having a business experience with a brand is related to the familiarity with that brand, which had been addressed in the Bapat model. According to this article the dimensions of brand experience include brand loyalty, brand satisfaction, brand identity, brand trust, and brand commitment (Bapat, 2017). According to an article, another important factor in 
brand's equity is image of the brand's country of origin in the minds of consumers. In Kim's article (2017), the impact of the country's symbols and stereotypes on the brand had been examined (Kim, 2017). The next model was the Sveiby model. Four factors affecting brand equity were considered: 1. Growth, 2. Innovation, 3. Productivity, 4. Stabilization (Osinski, 2017). Another criterion for brand value is the market value criterion. Standfield believes that the value of a brand is intrinsic to market value, which is a sustainable competitive advantage (Osinski, 2017). The other factor in brand equity had determined the level of corporate social responsibility. The purpose of corporate social responsibility is to observe the norms of society. In this study, Harjoto concluded that the corporate social responsibility of a company has a significant impact on its brand's value (Harjoto, 2017).

\section{Survey}

After reviewing the articles, the following factors were extracted for brand equity valuation:

Financial Indicators: Equity, Capital, Depreciation, Income, Cost, Financial Balance. Market: Two similar brands in two different markets can have different values. Brand personality: What style is the overall brand strategy? For example, an accountability brand or an active brand. Brand Age: Affects many factors such as loyalty and customer awareness. Brand quality: The quality of brand products. Brand Leadership: whether the brand is a market leader or not. Awareness: Awareness of customers about the brand. Trust: How much people trust in brand products? Loyalty: a higher degree of trust. Commitment: Customer commitment to purchase a brand in any circumstances. Quality of partners: Whatever the partners of a brand is better, its value goes up. Quality of Supply Chain: This is part of the brand's quality. Brand credibility: Credit in the market and in the supply chain. Brand allies: Brand as a member in stronger alliances. Brand Internal Relations: Improving internal communication has a positive impact on all sectors and increases value. Brand pricing policies. Quality of brand service. Brand Competitive Advantages. Brand Growth. Brand productivity. Brand ethical and social obligations. Brand premium. Brand Prestige.

After introducing of the above factors, a total of 50 experts from one of Iran's development organizations were asked to state which factors or factors among them are considered to be effective on the brand value of an organization? This organization is the largest of its kind in Iran. The activity scope of this organization compasses various fields, including oil and gas, mines, melting, locomotive manufacturing, renewable energy, automobile manufacturing, shipbuilding, and so on. This developed organization which has more than 50 years of experience, plays a huge role in creating various industrial infrastructures in Iran. All industrial projects of the Ministry of Industry, Mining and Trade of Iran are evaluated and implemented in this organization. Brand Value of this organization (as the parent organization), directly effects on the brand value of its subsidiaries. Table (1) shows the result of the survey.

Table (1): Result of the survey

\begin{tabular}{|c|c|c|}
\hline No. & Factor & $\begin{array}{c}\text { Number of } \\
\text { votes }\end{array}$ \\
\hline 1 & Financial Factors & 38 \\
\hline 2 & Trust & 36 \\
\hline 3 & Awareness & 33 \\
\hline 5 & Pricing & 33 \\
\hline 6 & Loyalty & 32 \\
\hline
\end{tabular}




\begin{tabular}{|c|c|c|}
\hline No. & Factor & $\begin{array}{c}\text { Number of } \\
\text { votes }\end{array}$ \\
\hline 7 & Brand Prestige & 20 \\
\hline 8 & Brand Services & 18 \\
\hline 9 & Quality & 17 \\
\hline 10 & Growth & 16 \\
\hline 11 & Leadership & 16 \\
\hline 12 & Age & 14 \\
\hline 13 & Efficiency & 14 \\
\hline 14 & Commitment & 12 \\
\hline 15 & market & 11 \\
\hline 16 & Alliances & 10 \\
\hline 17 & Internal Communications & 10 \\
\hline 18 & Ethical Commitments & 9 \\
\hline 19 & Premium & 7 \\
\hline 20 & Supply Chain & 6 \\
\hline 21 & Partner's Quality & 4 \\
\hline
\end{tabular}

\section{Results and Discussions}

The purpose of this study was to identify the factors influencing the brand value of a development organization. In this context, articles related to brand valuation were searched and selected in accordance with the research methodology (meta-analysis). While reviewing these articles, indicators were extracted to evaluate brand equity. By asking 50 experts from a development organization about the importance of the introduced indicators, it was obtained that according to financial indicators, brand trust, brand awareness and pricing, are the four most influential factors on the brand of an organization (Brand awareness and pricing with the same number of votes are ranked third). Also, the quality parameters of the partners, the supply chain and premium are the least important parameters affecting the brand value of the development organization.

For future studies, it is suggested that the impact of each of the parameters that have the greatest impact on the brand value of an organization is proposed. It is also suggested that in future projects, the extent to which each of the parameters that the experts consider to be more important on the brand of the development organization, and how they affect each other, are examined on other dimensions of the brand such as market share, competitive strategies, and so on.

\section{References}

Aaker, D. A. (1991). Managing Brand Equity - Capitalization on the Value of a Brand Name (first). New York, New York, USA: THE FREE PRESS.

Abril, C., \& Rodriguez-Cánovas, B. (2016). Marketing mix effects on private labels brand equity. European Journal of Management and Business Economics, 25(3), 168-175.

Agus Harjoto, M., \& Salas, J. (2017). Strategic and institutional sustainability: corporate social responsibility, brand value, and Interbrand listing. Journal of Product \& Brand Management, 26(6), 545-558. 
Anselmsson, J., Burt, S., \& Tunca, B. (2017). An integrated retailer image and brand equity framework: Re-examining, extending, and restructuring retailer brand equity. Journal of Retailing and Consumer Servi. Journal of Retailing and Consumer Services, 38(May), 194203.

Bapat, D. (2017). Article information: Impact of Brand Familiarity on Brands Experience Dimensions for Financial Services Brands.

Blackett, T. (1991). The Valuation of Brands. Marketing and Research Today, 21(5), 80-90.

Chih-Pin Lin, Cheng-Min Chuang, (2016) "Corruption and brand value", International Marketing Review, Vol. 33 Issue: 6, pp.758-780

Chow, H. wen, Ling, G. J., Yen, I. yin, \& Hwang, K. P. (2016). Building brand equity through industrial tourism. Asia Pacific Management Review, 22(2), 70-79.

Godey, B., Manthiou, A., Pederzoli, D., Rokka, J., Aiello, G., Donvito, R., \& Singh, R. (2016). Social media marketing efforts of luxury brands: Influence on brand equity and consumer behavior. Journal of Business Research, 69(12), 5833-5841.

Herrero, A., San Martin, H., Garcia de los Salmones, M. del M., \& Collado, J. (2017).

Examining the hierarchy of destination brands and the chain of effects between brand equity dimensions. Journal of Destination Marketing and Management, 6(4), 353-362.

Kim, N., Chun, E., \& Ko, E. (2017). Country of origin effects on brand image, brand evaluation, and purchase intention. International Marketing Review, 34(2), 254-271.

Krishnan, V., Sullivan, U. Y., Groza, M. D., \& Aurand, T. W. (2013). The Brand Recall Index: a metric for assessing value. Journal of Consumer Marketing, 30(5), 415-426.

Lassar, W., Mittal, B., \& Sharma, A. (1995). Measuring customer-based brand equity. Journal of Consumer Marketing, 12(4), 11-19.

Mishra, S., Singh, S. N., Fang, X., \& Yin, B. (2017). Impact of diversity, quality and number of brand alliance partners on the perceived quality of a new brand. Journal of Product \& Brand Management, 26(2), 159-176.

Motameni, R., \& Shahrokhi, M. (1998). Brand equity valuation: a global perspective. Journal of Product \& Brand Management, 7(4), 275-290.

Murphy, J. (1989). The Valuation of Brands. British Food Journal, 21(5), 80-90.

Osinski, M., Selig, P. M., Matos, F., \& Roman, D. J. (2017). Methods of evaluation of intangible assets and intellectual capital. Journal of Intellectual Capital, 18(3), 470-485.

Steenkamp, J.-B. (2014). How global brands create firm value: the 4V model. International Marketing Review, 31(1), 5-29. 
Vogel, A. T., \& Watchravesringkan, K. (2017). Consumer evaluations of trend imitation: brand equity, consumer attitudes and preference. Journal of Product \& Brand Management, 26(5), 516-527.

Zhang, J., \& He, Y. (2014). Key dimensions of brand value co-creation and its impacts upon customer perception and brand performance. Nankai Business Review International, 5(1), 4369. 